EDITORIAL

\title{
EDUCAÇÃO: DE DIREITO DE CIDADANIA \\ A MERCADORIA
}

\section{A}

última década do século XX e a primeira do século XXI estão servindo de cenário para o retorno da educação, em novo patamar, ao centro do debate público. Entretanto, no contexto de mudanças macroeconômicas globais, orientadas por Estados hegemônicos e organismos multilaterais a seu serviço, que contam com a anuência voluntária ou não dos demais países (subalternos e periféricos?), a educação, ao mesmo tempo em que é alvo da crítica de todos os matizes ideológicos por não responder às demandas sociais, passa por transformações de sua identidade histórica: de direito de cidadania herdado do ideário liberal, da Revolução Francesa e do Estado de BemEstar, ou socialista - parece transformar-se a cada dia em um bem privado ou mercantil, isto é, moeda de troca entre indivíduos, entre indivíduos e organizações comerciais nacionais ou transnacionais, e mesmo entre nações nas suas transações mercantes. A modernização conservadora do Estado e da sociedade estaria fazendo do campo educacional a mais nova fronteira de expansão do capital na dita Sociedade do Conhecimento. Não surpreende, pois, que a mercantilização dos serviços (antes, direitos) educacionais esteja há quase uma década na ordem do dia de AGCS/ о MC - desde as propostas americanas, australianas e neozelandesas para sua regulamentação - nem que a imprensa nacional noticie que "Fundos de investimento externos pretendem adquirir instituições [universidades] para depois vender participação", de modo similar ao que estaria ocorrendo com empresas de serviços de saúde, como redes de farmácias e laboratórios, ou comerciais, como as de comunicação e de energia, ou industriais, como as de alimentos e de agribusiness.

Além desses, listem-se entre os principais sintomas dessa profunda transformação identitária da educação em curso: 1) a estagnação ou redução do financiamento público, em especial da 
educação superior; 2) a grande expansão da educação privada lato e stricto sensu (nesse caso, a começar pela legalização das instituições educacionais com fins lucrativos) e a adoção de claros processos de mercantilização dos serviços; 3) a crescente privatização interna das instituições públicas via venda de serviços, consultorias e outros mecanismos, entre os quais se destacam as fundações privadas de apoio institucional; 4) o surgimento de novos modelos empresariais provedores de serviços educacionais com fins lucrativos (for profit) orientados pelo mercado, as universidades corporativas, escolas e universidades virtuais, os consórcios de instituições públicas e empresas privadas, as escolas autogestionadas e a franchising educacional; 5) os novos sistemas de coordenação, avaliação e controle que, estimulando a administração gerencial e a competição de tipo empresarial, submetem os subsistemas de ensino, inclusive os públicos, aos mecanismos e interesses do mercado e destroem a autonomia da instituição escolar; 6) a indústria dos dispositivos pedagógicos extra-escolares (softwares educativos, entre outros) para incremento da competitividade escolar, o mercado de produtos paraescolares e de serviços especializados, que incluem empresas prestadoras de serviços psicopedagógicos (tutorias remotas, entre outros), de acompanhamento de deveres de casa, de aulas particulares de recuperação e reforço.

Um grande arsenal de conceitos-chave, revestido em grande medida de semântica nova, tem sido utilizado para alimentar e viabilizar, sejam aquelas transformações macroeconômicas e estruturais de fundo, sejam as do campo educacional. Bourdieu \& Wacquant, em célebre artigo intitulado "La nouvelle vulgate planétaire" (L e M onde D iplomatique, maio de 2000), chamam a atenção para a estranha nova língua "cujo vocabulário, aparentemente surgido em lugar nenhum, está em todas as bocas: 'mundialização' e 'flexibilidade'; 'governança' e 'empregabilidade'; 'underclass' e 'exclusão'; 'nova economia' e 'tolerância zero'; 'comunitarismo', 'multiculturalismo' e seus primos 'pósmoderno', 'etnicidade', 'minoridade', 'identidade', 'fragmentação' etc.". Alertam, entretanto, para a surpreendente ausência de termos como capitalismo, classe, ex ploração, dominação, desigualdade, e que "tantos vocábulos peremptoriamente revogados sob o pretexto de obsolescência ou de impertinência presumidas - é o produto de um imperialismo propriamente simbólico". Alertam, igualmente, para seus efeitos poderosamente perniciosos, que 0 seriam ainda mais porque utilizados não apenas pelos neoliberais convictos, que, sob a capa de modernização, fazem tábula rasa de cem anos de conquistas sociais, mas 
também pelos produtores culturais (pesquisadores, escritores, artistas) e por militantes de esquerda que, em sua maioria, consideram-se progressistas.

No campo educacional, como de resto em todo o campo social, os conceitos que subjazem a essa cruzada mercantilizadora não são menos empobrecedores do discurso teórico e político-ideológico. Em recente texto intitulado "Público versus mercantil", na Folha de S. Paulo (19/6/2003), o sociólogo Emir Sader expunha o que ele chama de "Uma das operações teóricas e políticas mais bem-sucedidas do neoliberalismo", isto é, a instauração do debate em torno da oposiçãa entre estatal e privado. 0 debate posto nesse eixo impõe - segundo ele - "um campo duplamente favorável ao liberalismo, porque, por um lado, permite uma mais fácil desqualificação do estatal e, por outro, desloca um dos termos essenciais do debate: 0 público". Contra 0 estatal são lançadas as pechas de ineficiente, cobrador de impostos e mau prestador de serviços à população, além de burocrático, corrupto, opressor. Em favor do privado idealizam-se virtudes como as de espaço de liberdade individual, de criação, de imaginação e de dinamismo. Esquece-se de que " $O$ Estado brasileiro tem sido facilmente desqualificável, porque se tornou um Estado privatizado. Um Estado que arrecada do mundo do trabalho e transfere recursos para o setor financeiro, gastando mais com o pagamento dos juros da dívida que com educação e saúde. Um Estado que paga taxas de juros estratosféricas ao capital financeiro, mas remunera pessimamente seus professores e seus trabalhadores do setor de saúde pública, aqueles mesmos que prestam serviços à massa da população. (...) Por oposição, o privado surge como pólo privilegiado".

D e fato, enfatiza Sader, a oposição estatal x privado reduziria 0 debate a dois termos que não seriam necessariamente contraditórios: 0 estatal não seria um pólo, mas, sim, um campo de disputa, dominado hoje pelos interesses privados. Assim, o privado também não seria a esfera dos indivíduos, "mas dos interesses mercantis - como se vê nos processos de privatização, que não constituíram processos de desestatização em favor dos indivíduos, mas das grandes corporações privadas, aquelas que dominam 0 mercado -, a verdadeira cara por trás da esfera privada no neoliberalismo". Nesse esquema, o pólo oposto ao estatal "é a negação da cidadania, é o reino do mercado, aquele que, negando os direitos, nega a cidadania e o indivíduo como sujeito de direitos". A conclusão mais óbvia e definitiva é que: "A polarização essencial não se dá entre 0 estatal e 0 privado, mas entre 0 público e 0 mercantil". 
Como alertam Bourdieu \& Wacquant, o poder desse imperialismo simbólico se agrava quando se torna senso comum. Algo similar afirma Apple, em seu artigo nesta edição, ao mapear a modernização conservadora que se imporia como estratégia hegemônica mesmo entre os que lutam pelos direitos dos despossuídos de direitos. Políticas conservadoras, direitistas, que se apresentam freqüentemente como radicais e como soluções necessárias para um sistema educacional fora de controle e que não responderia às necessidades do povo. É este conservadorismo, lembra Apple, que avança e toma o lugar central em muitas nações, que toma conta de largos segmentos governamentais e de policy makers, e ainda é apropriado por grupos dos quais não se esperaria que 0 fizessem.

No rol desses conceitos-chave, para entender-se a guinada conservadora mercantil que assola o campo educacional, Apple lista mercados, padrões, prestação de contas (accountability), tradição, D eus, além de numerosos outros, com valência emocional diversa, que incluem os de democracia, liberdade, escolha, moralidade, família e cultura, aptos a prover suporte para os caminhos palmilhados por esse novo e diferente poder. A estes ainda se poderia acrescentar: quasemercado educacional, forças do mercado, decisões privadas, regulação, regulação pela oferta e pela procura, desregulação, controle, ranking, competências, qualidade total, acreditação, bem privado x bem público, eqüidade social, livre escolha escolar, escolas autogestionadas, organizações sociais, organizações públicas não-estatais, produtos paraescolares, capitalismo acadêmico etc.

Para analisar essa realidade acima apenas delineada em alguns de seus principais traços, mediante novas leituras com novas (e velhas!) categorias teóricas, E ducação \& Sociedade convidou um grupo selecionado de especialistas nacionais e estrangeiros. É assim que, de diferentes lugares teóricos e posições político-ideológicas, autores brasileiros, argentinos, mexicanos, americanos, ingleses, franceses e portugueses nos apresentam, nesta edição, instigantes reflexões sobre um conjunto muito significativo de aspectos deste mosaico formado pela temática da educação como direito de cidadania e sua acelerada transformação em semimercadoria ou mercadoria, simplesmente, no quase-mercado educacional, onde desponta em especial a histórica contradição público x privado ou, em termos mais adequados, público $\mathrm{x}$ mercantil.

Registre-se que este número especial de E ducacão \& Sociedade, além disso, retoma e aprofunda questões já levantadas em números 
anteriores, em particular no número especial de 2002 (v. 23, n. 80), no qual, sob o título "Políticas públicas para a educação: olhares diversos sobre o período de 1995 a 2002", procurou-se realizar um balanço crítico dessas políticas, inegavelmente marcadas por essa contradição.

Elizabeth de Almeida Silvares Pompêo de Camargo Ivany Rodrigues Pino José Augusto Pacheco Patrizia Piozzi Pedro G oergen Romualdo Portela de O liveira Valdemar Sguissardi (O rganizadores) 